\title{
Prognostic significance of early aortic remodeling in acute uncomplicated type $B$ aortic dissection and intramural hematoma: Tell us what to do
}

\author{
Jean Bachet, MD, FEBCTS
}

From the ADETEC, Suresnes, France.

Disclosures: Author has nothing to disclose with regard to commercial support.

Received for publication May 11, 2017; accepted for publication May 11, 2017; available ahead of print June 20, 2017.

Address for reprints: Jean Bachet, MD, FEBCTS, ADETEC, 1 rue Marcel Legras, 92150 Suresnes, France (E-mail: jean.bachet@yahoo.fr).

J Thorac Cardiovasc Surg 2017;154:1171-2

$0022-5223 / \$ 36.00$

Copyright (c) 2017 by The American Association for Thoracic Surgery

http://dx.doi.org/10.1016/j.jtcvs.2017.05.033

In this issue of the Journal, Sailer and coworkers ${ }^{1}$ report, through a study of the 1-, 2-, and 5-year evolution of uncomplicated type $\mathrm{B}$ aortic dissection (AD) and intramural hematoma (IMH), on a very interesting but rarely addressed matter of importance concerning the follow-up and the possible late treatment of these aortic syndromes. The article is very well organized and quite clearly written, and the information provided seems to be in line with what can be observed through daily practice or intuitively guessed.

The authors define 3 groups of evolution for the initially uncomplicated type B AD and 2 groups for type B IMH, in which the risk of late adverse events is quite different. They show that adverse events in IMH occurred mostly during the first year and at a low rate, whereas in type B AD the cumulative probability of adverse events continued to increase gradually over time during the entire follow-up period.

Thus, as it stands, this study seems perfectly contributory, providing good and useful information. Not totally, however. Indeed, one important point is not addressed. The authors do not specify their actual therapeutic attitude when observing the evolution of the various groups. What was the mode and the frequency of the surveillance during follow-up? What is the optimal medical treatment, and when should surgery or thoracic endovascular aneurysm repair (TEVAR) be proposed?

It is somewhat understandable that a long, extensive description of the medical and surgical or interventional treatments performed during follow-up could distract the reader from the main purpose of the study. Nevertheless, such information may be of importance if one wants to reduce the rates of adverse events, particularly the most deleterious ones.

Because adverse events rarely manifest during the first year in IMH, should computed tomography (CT) scanning be performed regularly during this period-for instance at discharge and then at 3, 6, and 12 months thereafter?

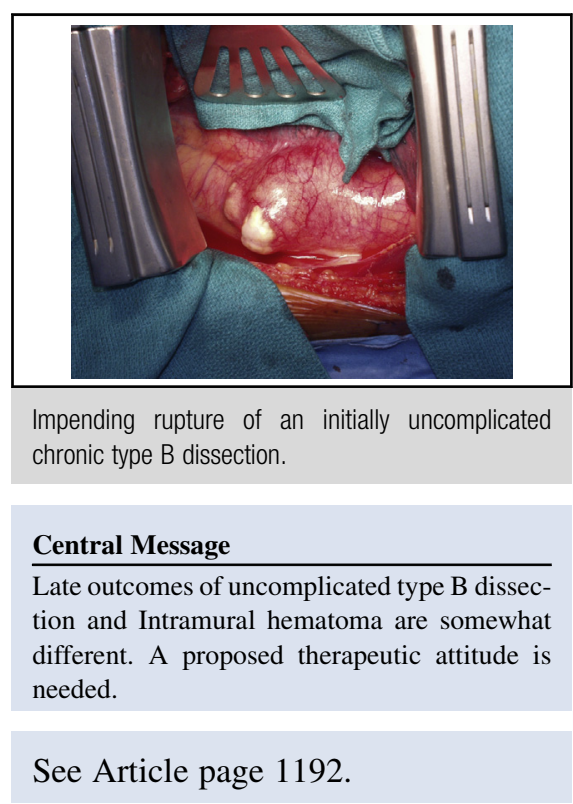

If the IMH resolves, should surveillance be waived? In uncomplicated chronic type $\mathrm{B} A D$, should a CT scan or any other suitable imaging be performed regularly throughout follow-up?

The most important unresolved question whether in cases of increasing aortic diameter, when is surgical or interventional treatment indicated? The answer is clear in patients with severe occurring or impending adverse events, such as rupture, malperfusion, recurring severe pain-but what about totally asymptomatic patients? Performing open surgery and possibly TEVAR in an asymptomatic, physically and socially active patient is a difficult decision, considering that such surgery can involve devastating complications, such as paraplegia or even death.

Alluding to this problem, the authors discuss the various US and European guidelines.

However, this does not shed much light on the matter, because guidelines differ somewhat and are modified from time to time, clearly demonstrating that they are only recommendations and not strong obligations. Therefore, considering the very important cohorts studied in the present report, it would have been helpful had the authors shared their present approach and explained whether the analysis of those cohorts had led them to 
modify their practice. Let's hope that they will in a future study on the same cohorts of patients satisfy this requirement of the readership and share their experience.

\section{Reference}

1. Sailer AM, Nelemans PJ, Hastie TJ, Chin AS, Huininga M, Chiu P, et al. Prognostic significance of early aortic remodeling in acute uncomplicated type b aortic dissection and intramural hematoma. J Thorac Cardiovasc Surg. 2017; $154: 1171-2$

Access to The Journal of Thoracic and Cardiovascular Surgery Online is reserved for print subscribers!

Full-text access to The Journal of Thoracic and Cardiovascular Surgery Online is available for all print subscribers. To activate your individual online subscription, please visit The Journal of Thoracic and Cardiovascular Surgery Online, point your browser to http://www.mosby.com/itcvs, follow the prompts to activate your online access, and follow the instructions. To activate your account, you will need your subscriber account number, which you can find on your mailing label (note: the number of digits in your subscriber account number varies from 6 to 10). See the example below in which the subscriber account number has been circled:

\section{Sample mailing label}

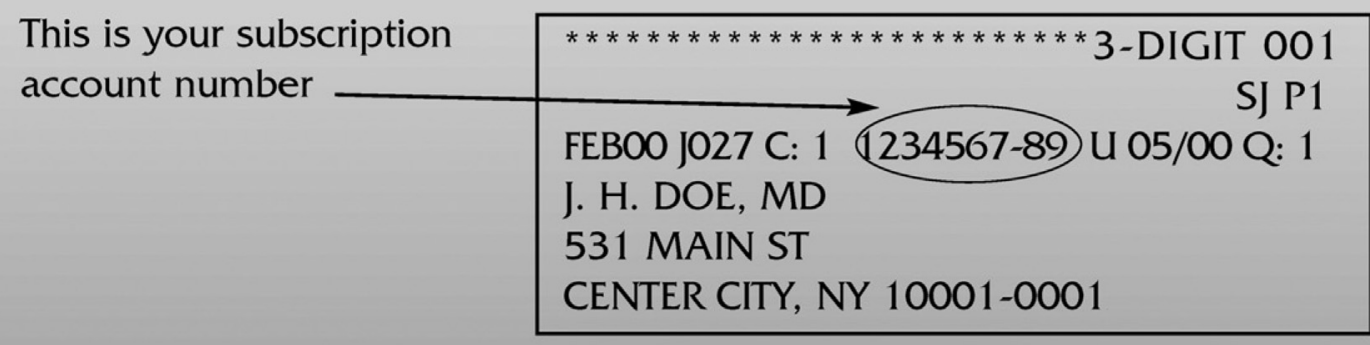

Personal subscriptions to The Journal of Thoracic and Cardiovascular Surgery Online are for individual use only and may not be transferred. Use of The Journal of Thoracic and Cardiovascular Surgery Online is subject to agreement to the terms and conditions as indicated online. 